\title{
Laboratorial Diagnosis of Lymphocytic Meningitis
}

\author{
Sérgio Monteiro de Almeida, Meri Bordignon Nogueira, Sonia Mara Raboni and Luine Rosele Vidal
}

Federal University of Paraná; Curitiba, PR, Brazil

\begin{abstract}
Meningitis is the main infectious central nervous system (CNS) syndrome. Viruses or bacteria can cause acute meningitis of infectious etiology. The term "Aseptic Meningitis" denotes a clinical syndrome with a predominance of lymphocytes in the cerebrospinal fluid (CSF), with no common bacterial agents identified in the CSF. Viral meningitis is considered the main cause of lymphocyte meningitis. There are other etiologies of an infectious nature. CSF examination is essential to establish the diagnosis and to identify the etiological agent of lymphocytic meningitis. We examined CSF characteristics and the differential diagnosis of the main types of meningitis. Key-Words: Cerebrospinal fluid, lymphocytic meningitis, viral meningitis, meningitis.
\end{abstract}

Central Nervous System (CNS) infections classically are classified as meningitis and encephalitis [1]. Meningitis is the most common infectious CNS syndrome, defined as an inflammation of the meninges. The clinical symptoms are fever, malaise, vomiting, and in some cases, petechial rashes. Signs of meningeal irritation include neck stiffness, Kernig's sign, (an inflection of the knee when the limb is placed at a certain degree of relative inflection to the trunk), and Brudzinski’s sign, (an involuntary inflection of the limb following a head inflection). These signs are poorly sensed in adults. In one study of adults, both Kernig and Brudzinski signs had a sensitivity of only $5 \%$, while the sensitivity of nuchal rigidity was $30 \%$. The nonspecific nature of the symptoms and clinical signs means that we often over-treat and look to other exams to confirm the diagnosis [2].

Signs of meningeal irritation are rare among younger children. Small children can present other signs, such as an inability to feed, vomiting, drowsiness, convulsions, and a bulging fontanel. Table 1 presents the classification of meningitis in accordance with duration.

Encephalitis includes clinical signs of brain parenchyma involvement, fever, chronic headache, conscience alteration, which can be followed by focal neurological signals or seizures of recent onset. Meningoencephalitis occurs when meningitis is followed by involvement of brain parenchyma.

Acute meningitis with infectious etiology is viral or bacterial. From the first month of life, the bacteria $H$. influenzae, N. meningitidis and S. pneumoniae are responsible for 70 to $90 \%$ of the cases of acute bacterial meningitis in all regions of the world $[3,4]$. Infections by $H$. influenzae have been significantly reduced because of systematic vaccination. The methods used for etiological diagnosis for acute bacterial meningitis are indicated in Table 2 [5-11].

Received on 11 February 2007; revised 10 August 2007.

Address for correspondence: Dr. Sérgio Monteiro de Almeida. Hospital de Clínicas, Universidade Federal do Paraná, Seção de Virologia. Rua Padre Camargo, 280. Curitiba, PR, Brazil. Zip Code: 80.060240. Phone/ Fax (041)3360-7974.

The Brazilian Journal of Infectious Diseases 2007;11(5):489-495. (C) 2007 by The Brazilian Journal of Infectious Diseases and Contexto Publishing. All rights reserved.
Table 1. Classification of meningitis

\begin{tabular}{lll}
\hline Type & Duration & Etiology \\
\hline Acute & $<4$ weeks & Infectious \\
& & Non-infectious \\
Recorrent & Multiple acute & Infectious \\
& Episodes, & Non-infectious \\
& duration $<4$ weeks & \\
Cronic & $>4$ weeks & Infectious \\
& & Non-infectious \\
\hline
\end{tabular}

Table 2. Etiological diagnostic methods for acute bacterial meningitis

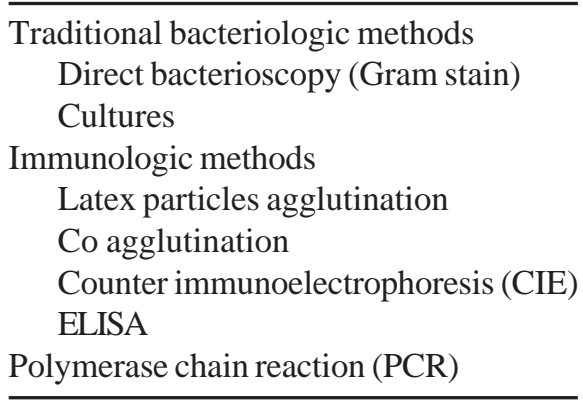

Chronic meningitis of infectious causes is caused by tuberculosis, syphilis, fungus (mainly Cryptococcus neoformans), cysticercosis and histoplasmosis, amongst other causes [12].

Aseptic means, according to the Oxford Dictionary, free from putrefaction or blood poisoning and absence of pathogenic germs. The term "Aseptic Meningitis" is related to the clinical syndrome of inflammation of the meninges, with predominance of lymphocytes in the cerebrospinal fluid (CSF), and no common bacterial agents in the CSF. The absence of signs of encephalic parenchyma involvement is implicit (encephalitis). Many authors consider the term aseptic meningitis to be synonymous with viral meningitis, although lymphocyte meningitis would be more appropriate. Though viral meningitis is the main cause of increased lymphocytes in the CSF, there are other etiologies of infectious nature (Table 3) [13-15]. 
Table 3. Etiology of lymphocytic meningitis

\begin{tabular}{ll}
\hline Infectious & Non-Infectious \\
\hline Virus & Autoimmune diseases \\
Mycobacterium & Carcinomatous meningitis \\
Syphilis & Parameninges infection \\
Cryptococcus & Medicamentous \\
Lysteria & \\
Brucella & \\
Mycoplasma & \\
Neurocysticercosis & \\
Toxoplasmosis & \\
Leptospirose & \\
\hline
\end{tabular}

\section{Diagnosis of Lymphocytic Meningitis}

When there is clinical suspicion of meningitis, analysis of the CSF is mandatory. CSF examination is essential to establish the diagnosis and to identify the etiological agent. CSF characteristics of the main types of meningitis are indicated in Table 4 [8,16-18].

The preferential site for CSF collection is lumbar, at the level of the dural sack $[19,20]$. A cisternal puncture, at the level of the magna cistern, has restricted indications nowadays [21]. The only absolute indication for cisternal puncture is intracranial hypertension or dermic/epidermic infection in the lumbar region. The lumbar puncture must obligatorily be done when there is suspicion of a medullar process; in these cases, if the puncture is done at the subocciptal level, the CSF can remain without alterations. Another location for CSF collection is ventricular. Ventricular puncture is always a neurosurgical procedure; it is not the place of choice for CSF collection. It is mainly carried out in children with an open fontanel, in neurosurgical patients or in those with problems of ventricular shunt [14].

The best test to differentiate bacterial from viral meningitis is the CSF lactate test. Lactate levels are particularly important when CSF Gram staining is negative and there is a predominance of polymorphonuclear (PMN) cells, with low glucose in the CSF [20]. CSF lactate concentrations greater than $3.5 \mathrm{mmol} / \mathrm{L}$ are characteristic of acute bacterial meningitis. As the lactate concentration in the CSF is independent of that of serum, there is no necessity to collect matched serum. CSF lactate levels are also useful for the diagnosis of post-surgical acute-bacterial meningitis, when there is no specific increase in cells and proteins [22-24].

Lumbar puncture repetition is recommended for a patient with fever and chronic headache that does not disappear after some days, for patients with predominance of polymorphonuclear leukocytes, or low glucose in the CSF, or in case of a doubt in the initial diagnosis. As molecular biology studies of the CSF continue to improve and new diagnostic techniques become more readily available, the etiological agents of viral meningitis will be identified more frequently [25-27].

PMN predominance (50\%) can occur within the first six hours of the onset of viral meningitis; after this time there is a change in the characteristics of the CSF to the typical pattern of viral meningitis $[14,15,25,27,28]$.

\section{Quantity of CSF Collected}

To determine the quantity of CSF to be collected, the CSF analyses that will be requested (Table 5) must be considered. In general, 10 to $15 \mathrm{~mL}$ of CSF are collected for diagnostic purposes; $500 \mathrm{~mL}$ of CSF ( $0.4 \mathrm{~mL} / \mathrm{min})$ are produced per day. The average time for total renewal of the CSF is from four to four hours. The 10 to $15 \mathrm{~mL}$ removed will be renewed in about 30 minutes.

To look for alcohol-acid resistant bacilli (BAAR), fungi or neoplasic cells, $5 \mathrm{~mL}$ are necessary for each analysis. Moreover, more than three serial CSF punctures increase the sensitivity of such samplings.

The CSF total cell number must be analyzed as soon as possible, within at least two hours after the lumbar puncture. Cell destruction, precipitation and fibrin formation begin immediately. These can interfere significantly with cell counts. If the CSF will not be analyzed immediately, the sample must be kept under refrigeration [14]. Almost 40\% of the WBCs are

Table 4. Normal CSF characteristics and main pathological alterations

\begin{tabular}{|c|c|c|c|c|}
\hline \multirow[b]{2}{*}{ Characteristics } & \multirow[b]{2}{*}{ Normal } & \multicolumn{3}{|c|}{ Meningitis } \\
\hline & & Acute bacterial & Viral & Chronic \\
\hline Pressure $\left(\mathrm{mm} / \mathrm{H}_{2} \mathrm{O}\right)$ & $100-200$ & $\mathrm{~N}$ or $\uparrow$ & $\mathrm{N}$ or $\uparrow$ & $\mathrm{N}$ or $\uparrow$ \\
\hline Aspect & Clear & Turbid/purulent & clear/cloudy & Clear/cloudy \\
\hline Color & Clear & white & Clear & Clear/white \\
\hline Cytology $\left(\mathrm{mm}^{3}\right)$ & Until 4 & $>1,000$ & $500-1,000$ & $<500$ \\
\hline Cell type & Lymphocytes & Neutrophils & Lymphocytes & Lymphocytes \\
\hline Protein (mg/dL) & $\begin{array}{l}\text { V 5-10 } \\
\text { SO } 10-25 \\
\text { L 15-45 }\end{array}$ & $\uparrow \uparrow$ & Normal or $\uparrow$ & Normal or $\uparrow$ \\
\hline Glucose (mg/dL) & $2 / 3$ from serum & $\downarrow$ & Normal & Normal or $\downarrow$ \\
\hline Lactic acid (mmol/L) & $<3.5$ & $>3.5$ & $<3.5$ & $<3.5$ \\
\hline
\end{tabular}


Table 5. Minimum volume of CSF necessary for routine analyses

\begin{tabular}{lc}
\hline Exam & (mL) \\
\hline Complete CSF (glucose*, protein, global & 3 \\
$\quad$ cytology and differential) & \\
Protein Electrophoresis & 5 \\
Lactate & 1 \\
Immunological reactions & 2 \\
Direct bacterioscopy and cultures** & 2 \\
\hline
\end{tabular}

*Concomitant collection of serum glucose. ${ }^{* *} \mathrm{CSF}$ culture must be collected in an appropriate tube with chocolate agar.

destroyed after two hours at room temperature and at $4^{\circ} \mathrm{C}$ $15 \%$ are destroyed. One hour after the collection there is a $32 \%$ reduction in the initial counts of neutrophils, and after two hours, $50 \%$ are lost. There is no significant reduction of lymphocytes or monocytes up to three hours after collection.

The normal number of WBCs in the CSF in adults varies from 0 to 3 cells $/ \mathrm{mm}^{3}$, or according to some authors, a maximum of 5 cells $/ \mathrm{mm}^{3}$ [14]. In children less than one year old, it varies from 0 to 30 cells $/ \mathrm{mm}^{3}$; however, there is no absolute consensus on the normal values of CSF cells in children $[15,29,30]$. Normal CSF contains a small number of lymphocytes and monocytes. The reference values are indicated in Table 6. The lymphocytes present in the CSF are similar to those in the peripheral blood. Small lymphocytes predominate, and 75 to 95\% are T lymphocytes [31].

Table 6. Normal differential CSF cytology

\begin{tabular}{lcc}
\hline & Adults & Newborns \\
\hline Lymphocytes & $60+20 \%$ & $20+15 \%$ \\
Monocytes & $30+15 \%$ & $70+20 \%$ \\
Neutrophils & $2 \%$ & $4 \%$ \\
\hline
\end{tabular}

\section{Lymphocytic Meningitis with Infectious Etiology \\ Viral Meningitis}

Viral meningitis is a worldwide disease, which can be either sporadic or epidemic. Despite the low mortality rates, there can be high morbidity [25]. The main viruses causing meningitis are indicated in Table 7.

Non-polio enteroviruses are responsible for most cases of viral meningitis (50\% to $80 \%$ ), especially during summer. Within the enterovirus group, there is an important further division into the Picornaviridae family: Echovirus $[4,5,7,10,12,16,22,31]$, the Polioviruses and the Coxsackieviruses of groups A and B 1,2. Enterovirus numbers 70 and 71 show a strong neurotropism, which is associated with meningoencephalitis, polio-like paralytic syndromes, Guillain Barré Syndrome, as along with meningitis. Coxsackie virus sub-group B is responsible for $60 \%$ of cases of meningitis among children less than three years old [25].
Table 7. Virus responsible for lymphocytic meningitis

\begin{tabular}{lll}
\hline Common & Less frequent & Rare \\
\hline Enterovirus & HSV-1 & Adenovirus \\
Coxsackie virus A e B & LCV & CMV \\
Echovirus & Mumps & EBV \\
Arbovirus* & & Influenza A, B \\
HIV & & Measles \\
HSV-2 & & Parainfluenza \\
& & Rubella \\
& & VZV \\
& & HHV-6 \\
\hline
\end{tabular}

*The types of arbovirus are different depending on the area, it is important to investigate areas or countries visited by the patients. LCV=Lymphocytic choriomeningitis virus.

The viruses of the herpes family collectively are responsible for $4 \%$ of the cases of meningitis. Meningitis more frequently is caused by HSV-2; HSV-1, 2 and EBV are associated with recurrent lymphocytic meningitis [25].

Almost 5\% to $10 \%$ of HIV positives have meningitis at any phase of the infection; however, it is more frequent during the seroconversion period. The ELISA test for anti-HIV antibodies in the CSF and in serum is generally negative in this phase. For diagnosis, the patients with suspicion of meningitis due to HIV must be followed and the anti-HIV ELISA of the serum repeated, or the CSF-HIV-viral load can be determined.

Parotid disease can be associated with meningitis in $10 \%$ to $20 \%$ of the cases; it is more frequent during winter months, and in male patients in a $3 / 1$ ratio.

Laboratorial investigation of lymphocytic meningitis is shown in Table 8. The laboratory techniques for viral detention are: viral isolation in cell culture (done in reference laboratories) and detection of the viral genome using RT-PCR or PCR.

Specific antibody anti-virus detection, which can be useful, is in general gradually being substituted by molecular techniques of genome amplification (RT-PCR/PCR). Other clinical materials, such as feces, urine, and blood, can be analyzed in association with the CSF. However positivity of the reaction does not confirm CNS infection [32].

Herpes encephalitis, along with the infection for HSV-1, is diagnostically different from meningitis. The CSF is altered in $97 \%$ of the cases. However, there are no pathognomonic alterations. There is an increase in WBCs, from 5 to 500 cells/ $\mathrm{mm}^{3}$, with a predominance of lymphocytes, moderate CSF total protein increase and normal or slightly reduced glucose [24,34]. The presence of red blood cells, in the absence of traumatic lumbar puncture, occurs in $40 \%$ of the cases and xantochromic CSF occurs in $11 \%$ of cases. These two CSF characteristics help to distinguish the diagnosis from other types of encephalitis [14]. The increase in the IgG levels occurs after the second week of illness. Specific levels of CSF anti-HSV IgG are elevated, and correspond to the increase in the serum. They can remain high three months to three years after the 
Table 8. Laboratorial investigation of lymphocytic meningitis

\begin{tabular}{ll}
\hline LCR & Serum \\
\hline RT-PCR to Enterovirus & Anti HIV \\
PCR to HSV2 DNA & VDRL/ FTA-ABS \\
PCR to EBV DNA & \\
PCR to CMV & \\
PCR to HIV-1 RNA & \\
VDRL & \\
ELISA to neurocysticercosis & \\
Direct research of BAAR* & \\
M. tuberculosis culture & \\
PCR to M. tuberculosis & \\
Capsular antigen to C. neoformans, latex** \\
Histoplasmosis research \\
Neoplasic cells
\end{tabular}

Bacterial infections always must be ruled out. *10 mL to direct search. ${ }^{* *}$ C. neoformans capsular antigen could be associated by latex agglutinations in the urine or serum.

acute illness [35]. Most of the patients have developed serum antibodies against HSV previously; therefore serological tests do not have a diagnostic value. A fourfold increase in serum antibodies does not represent sensitivity or specificity. There is intrathecal anti-HSV antibody synthesis against HSV; an increase of four times in these antibodies or an increase in the relation of anti-HSV antibodies in the CSF/serum have diagnostic value; however, this increase occurs slowly and is used as diagnostic confirmation retrospectively [36,37]. Detection of specific antibody anti-HSV can be calculated through the relation (antibodies index - AI) between the CSF/ serum quotients for the specific antibodies (Q spec) and the IgG quotient (Q IgG), AI = Q spec/Q IgG. Values greater than 1.5 indicate local synthesis of specific antibodies [32,38-40]. The polymerase chain reaction (PCR) in the CSF, to amplify the HSV DNA, is the method of choice for HSV diagnosis [38,41-43]. The PCR is positive 24 to 48 hours after the beginning of neurological symptoms and remains positive during two to five days after the beginning of treatment with antivirals.

The sensitivity of the PCR reaction depends on a series of factors. The sensitivity of PCR for HSV is $94 \%$, the specificity is $98 \%$, positive predictive value is $95 \%$ and negative predictive value is $98 \%$ [33,38,44-48].

There is a relation between the detection of virus by PCR in the CSF and the onset of neurological symptoms. The highest positivity of the PCR for enterovrrus occurs between the 3rd and the 14th day [49].

\section{Neurosyphilis}

CSF VDRL is the gold standard for the diagnosis of neurosyphilis; it has a sensitivity of $30 \%$ to $70 \%$ [50]. False positive results are described only in cases of traumatic lumbar puncture. A positive CSF VDRL establishes the diagnosis; however, if negative, the CSF VDRL does not exclude the
Table 9. Sensibility and specificity of PCR for virus in the CSF

\begin{tabular}{lcc}
\hline Virus & Sensibility (\%) & Specificity (\%) \\
\hline HSV 1 & $>95$ & 100 \\
CMV & $80-100$ & $75-100$ \\
VZV & & 100 \\
EBV & 97 & 100 \\
JC virus & $74-92$ & $92-96$ \\
Enterovirus & 97 & 100 \\
\hline
\end{tabular}

diagnosis. The CSF FTA-ABS is $100 \%$ positive in cases of neurosyphilis and negative in $100 \%$ of the cases without syphilis; $23 \%$ of the cases with systemic syphilis are positive. The percentage of false positive results is as high as the serum FTA-ABS [51]. The CSF FTA ABS sensitivity is 100\%, and the specificity varies from $39 \%$ to $89 \%$ [32,52].

Other causes of lymphocytic meningitis should be suspected, depending upon the region of origin of the patient or on his immunological status [53].

\section{Lymphocytic Meningitis with Non-Infectious Etiology \\ Chemical Meningitis}

Some intrathecal medicines, such as antibiotics, including metrotexate, anaesthetics, aracytin, baclofen, corticoids, or contrast chemicals, can cause chemical meningitis. The presence of blood in the CSF due to subarachnoid hemorrhage also can cause an increase in CSF cells and low glucose. Normal CSF does not have red blood cells. When there are red blood cells in the CSF, it is important to separate subarachnoid hemorrhage from traumatic lumbar puncture (Table 10).

Macrophages with red blood cells in their interior have no value to differentiate HAS from traumatic lumbar puncture, because macrophages persist with phagocytic activity in vitro more than six hours. Crenate red blood cells also are not important in the differential diagnosis. The first three criteria provide the differential diagnosis in almost $80 \%$ of the cases. A CSF with traumatic puncture has an increase in cells and proteins, due to the leakage of these elements from the blood. The correction of total CSF-cell number is done by following

Table 10. Differential diagnosis between subarachnoid hemorrhage and traumatic lumbar puncture

\begin{tabular}{lll}
\hline & HAS & $\begin{array}{l}\text { Traumatic } \\
\text { lumbar puncture }\end{array}$ \\
\hline $\begin{array}{l}\text { 3Tubes(Tuffier Millian) } \\
\text { Supernatant post-centrifuge } \\
\text { Clot }\end{array}$ & $\begin{array}{l}\text { Same } \\
\text { Xantochromic } \\
\text { Macrophages with }\end{array}$ & $\begin{array}{l}\text { Different } \\
\text { Clear }\end{array}$ \\
hemosiderin & Present & Present \\
Hemoglobinxbilirubin(\%) & Absent \\
& predinubin & $\begin{array}{l}\text { Hemoglobin } \\
\text { predominance }\end{array}$ \\
\hline
\end{tabular}


the relation:

Corrected WBCs $=$ CSF WBCs - blood WBCs X CSF RBC
blood RBC

Practically, it is considered that each 700 to 1,000 red blood cells $/ \mathrm{mm}^{3}$ increases $1 \mathrm{cell} / \mathrm{mm}^{3}$ in the CSF and $1 \mathrm{mg} / \mathrm{dL}$ of total CSF protein. This correction is valid only for traumatic lumbar puncture; in the case of HSA there is increase in total CSF cells due to chemical meningitis caused by the presence of blood in the subarachnoid space.

\section{Medicamentous Meningitis}

The systemic use of some medicines, such as non-steroid anti-inflammatory drugs, antibiotics with sulfa, intravenous immunoglobulin, isoniazide, and Muromonab-CD3, can cause an increase of WBC in the CSF, with predominance of lymphocytes [14,54,55].

\section{Carcinomatous Meningitis}

The hypothesis of CNS involvement by malignant neoplasms must be examined in a patient with known malignant neoplasms and neurological symptoms. Malignant cells from a variety of tumors, metastatic or primary, can be detected in the CSF. Any type of neoplasm can spread to the leptomeninges. This dissemination occurs more frequently in acute hematological diseases, such as leukemia and lymphomas. Among solid tumors, the dissemination is more frequent with melanomas and breast or lung cancer. Among CNS primary tumors, tumor cells are more commonly found in the CSF in gliomas and medulloblastomas, due to their higher incidence and tendency to spread into the subarachnoid space. The frequency of CNS primary lymphomas has increased over time and is particularly high in patients with cellular-immunity alterations, such as HIV [56-59].

The positivity rate of detecting malignant cells in the CSF varies in the literature, but it is around $24 \%$, and it is assumed to depend on several factors, such as histological confirmation, localization of CSF collection, and CSF-processing methodology [60-62]. The sensitivity of detecting malignant cells in the CSF changes in accordance with the type of neoplasm, and with anatomic location, as well as with meningeal involvement and its extension and the number of malignant cells in the CSF [67]. Primary cerebral tumors that exfoliated cells to the CSF were all located adjacent to the ventricle. In contrast, cells from tumors deeply localized in cerebral parenchyma are more difficult to find in the CSF [6368].

In the specific case of lymphomas, some markers can help to differentiate the total cell number increase from an inflammatory reaction or a CNS infiltration. For example, interleukin-10 (IL-10), a B-cell growth and differentiation factor, is normally undetectable in the CSF. Systemic lymphoma cells produce IL-10. Elevated levels of interleukin-6 (IL-6), an inflammatory cytokine produced by $\mathrm{B}$ and $\mathrm{T}$ lymphocytes, have been found in infectious and noninfectious nonmalignant inflammatory disorders. Elevated IL-10 with an IL-10 to IL-6 ratio greater than 1.0 is a strong predictor of the presence of lymphoma cells in the CSF. Alternatively, an IL-10 to IL-6 ratio of less than 1.0 is characteristic of an infectious or noninfectious nonmalignant inflammatory disorder [57,69,70].

Methods with more sensitivity and specificity than cellular morphology are necessary to correctly identify malignant cells in the CSF. Although CSF cytology is useful, malignant cells are not detected in as many as one third of patients who have compelling clinical or radiographic evidence of neoplastic meningitis. Novel procedures are being tested that may enhance the early identification of malignant cells in the CSF. Currently, the diagnosis generally is made after the onset of neurological manifestations and heralds a rapidly-fatal course for most patients. Immunocytochemistry techniques, immunophenotyping and biochemical or immunological markers can help in this diagnosis [56,57,66,71-78]. The analysis of CSF biochemical and cellular characteristics, although not specific for the diagnosis of malignant involvement of the CNS, is important and can help with the diagnosis of CNS neoplasms, when associated with other clinical or biomarker characteristics.

\section{References}

1. Scheld W.M., Whitley R.J., Marra M.C. Infections of the Central Nervous System. Philadelphia, Lippincott, Williams \& Wilkins, 2004:5-30.

2. Thomas K.E., Hasbun R., Jekel J., et al. The diagnostic accuracy of Kernig's sign, Brudzinski's sign, and nuchal rigidity in adults with suspected meningitis. Clin Infect Dis 2002;35:46-52.

3. Quagliarello V.J., Scheld W.M. Treatment of bacterial meningitis. N Engl J Med 1997;336:708-16.

4. Schlech W.F. The epidemiology of bacterial meningitis. Antibiot Chemother 1992;45:5-17.

5. Almeida S.M., Reis Filho J.B. Meningites bacterianas agudas: estudo comparativo dos métodos de diagnóstico etiológico. Arquivos de Neuro-Psiquiatria 1992;50(Suppl.):56.

6. Almeida S.M., Reis Filho J.B. Meningites bacterianas agudas: Avaliação da Precisão do Látex e da Contra-imunoeletroforese. Arquivos de Neuro-Psiquiatria 1992;50(Suppl.):56.

7. Almeida S.M., Reis Filho J.B. Associação de métodos bacteriológicos tradicionais e imunológicos no diagnóstico etiológico das meningites bacterianas agudas. Arquivos de NeuroPsiquiatria 1994;52(Suppl.):048.

8. Klein J.O., Feigin R.D., McCracken Jr. G.H. Report of the task force on diagnosis and management of meningitis. Pediatrics 1986;78(Suppl.5).

9. Pfister H.W., Roos K.L. Bacterial meningitis. In Roos KL ed, Principles of neurologic infectious diseases. 13-28. Mc GrawHill, 2005. New York.

10. Kleine T.O., Zwerenz P., Zofel P., et al. New and old diagnostic markers of meningitis in cerebrospinal fluid (CSF). Brain Research Bull 2003;61:287-97.

11. Ringelmann R., Heym B., Kniehl E. Role of immunological tests in diagnosis of bacterial meningitis. Antibiot Chemother 1992;45:68-78.

12. Zunt J.R., Marra C. Cerebrospinal fluid testing for the diagnosis of Central Nervous System Infection. Neurologic Clinic 1999; $17: 675-90$. 
13. Coyle P.K. Overview of acute and chronic meningitis. Neurologic Clinic 1999;17(4):711-36.

14. Fishman R.A. Cerebrospinal Fluid in Diseases of the Nervous System. Philadelphia, Saunders, 1992; 431p.

15. Krieg A.F., Kjeldsberg C.R. Cerebrospinal fluid and other body fluids. In: Henry J.B., ed. Clinical diagnosis and management by laboratory methods. Philadelphia, WB Saunders. Philadelphia, 1991. 443-73p.

16. Addy D.P. When not to do a lumbar puncture. Arch Dis Child 1987;62:873-5

17. Clough C., Pearce J.M.S. Lumbar puncture. Br Med J 1980;2:297300.

18. Cutler R.W.P., Spertell R.B. Cerebrospinal fluid: a selective review. Ann Neurol 1982;11:1-10.

19. American Academy of Neurology. Report of the Quality Standards Subcommittee. Practice parameters: lumbar puncture. Neurology 2005;65:510-12.

20. Puccioni-Sohler M., Machado L. dos R., Canuto R., et al. Cerebrospinal fluid puncture, consent inform, and ethics in research: the Brazilian Academy of Neurology recommendations. Arq Neuropsiquiatr 2002;60:681-4.

21. Portela L.A., Souza V., Pahl F.H., Cardoso A.C., et al. Laceration of the posterior inferior cerebellar artery by suboccipital puncture of the cisterna magna: case report. Arq Neuropsiquiatr 2004;62:882-4

22. Cunha B.A. The usefulness of CSF lactic acid levels in central Nervous System infections with decreased CSF glucose. Clin Infect Dis 2004;38:1260-61

23. Aurelius E., Johanson B.O. Rapid diagnosis of herpes simplex encephalitis by nested PCR. Lancet 1991;337:189-92.

24. Blume G.M., Tyler K.L. Herpes simplex encephalitis. In: Feldmann E. Current diagnosis in neurology. 1994, Mosby, St Louis. p.8892.

25. Baringer J.R. Viral infections. In: Asbury A.K., McKhann G.M., McDonald W.I., ed. Diseases of the nervous system: clinical neurobiology. 2ed. W.B. Saunders, Philadelphia. 1992. p.1298311.

26. Ponka A., Ojala K., Teppo A.M., Weber T.H. The differential diagnosis of bacterial and aseptic meningitis using cerebrospinal fluid laboratory tests. Infection 1983;11:129-31.

27. Rotbart H.A. Viral meningitis and the aseptic meningitis syndrome. In: Scheld W.M., Whitley R.J., Durack D.T. Infections of the central nervous system. Raven Press, 1997, New York, p.1940 .

28. Matthews P.M., Arnold L.D. Diagnostic tests in neurology. New York, Churchill Livingstone. New York, 1991. 3-38p.

29. Carraccio C., Blotny K., Fisher N.C. Cerebrospinal fluid analysis in systemically ill children without central nervous system disease. Pediatrics 1995; 96: 48-51.

30. Sarff L.D., Platt L.H., McCracken G.H. Cerebrospinal fluid evaluation in neonates: composition in high-risk infants with and without meningitis. J Pediatr 1976;88:473-7.

31. Svenningsson A., Andersen O., Edsbagge M., Stemme S. Lymphocyte phenotype and subset distribution in normal cerebrospinal fluid. J Neuroimmunol 1995;63:39-46.

32. Matthews P.M., Arnold L.D. Diagnostic tests in neurology. New York, Churchill Livingstone, 1991. 3-38p.

33. Tyler K.L. Update on herpes simplex encephalitis. Rev Neurol Dis 2004;1:169-78.

34. Steiner I., Budka H., Chaudhuri A., et al. Viral encephalitis: a review of diagnostic methods and guidelines for management. European J Neurol 2005,12:331-43.

35. Kapur N., Barker S., Burrows E.H., et al. Herpes simplex encephalitis: long term magnetic resonance imaging and neuropsychological profile. J Neurol Neurosurg Psych 1994;57:1334-42.

36. Whitley R.J., Tilles J., et al. Herpes simplex encephalitis: clinical assessment. JAMA 1982;247:317-20.
37. Whitley R.J., Schlitt M. Encephalitis caused by Herpesviruses, including B virus. In: Scheld M.W., Whitley R.J., Durack D.T., ed. Infections of the central nervous system. Raven Press, New York, 1997, p.41-86.

38. Koskiniemi M., Vaheri A., Taskinen E. Cerebrospinal fluid alterations in herpes simplex virus encephalitis. Rev Infect Dis 1984;6:608-18.

39. Monteyne P., Albert F., Weissbrich B., et al. The detection of intrathecal synthesis of anti-Herpes simplex IgG antibodies: comparison between an antigen-mediated immunoblotting technique and antibody index calculations. J Med Virol 1997;53:324-31.

40. Reiber H., Lange P. Quantification of virus-specific antibodies in cerebrospinal fluid and serum: sensitive and specific detection of antibody synthesis in brain. Clin Chem 1991; 7:1153-60.

41. Al-Shekhlee A., Kocharian N., Suarez J.J. Re-evaluating the diagnostic methods in herpes simplex encephalitis. Herpes 2006; 13:17-22

42. Anderson N.E., Powell K.F., Croxson M.C. A polymerase chain reaction assay of cerebrospinal fluid in patients with suspected herpes simples encephalitis. J Neurol Neurosurg Psych 1993;56:520-5.

43. Domingues R.B., Tsanaclis A.M.C., Pannuti C.S., et al. Evaluation of the range of clinical presentations of herpes simplex encephalitis using polymerase chain nreaction assay of cerebrospinal fluid samples. Clin Infect Dis 1997;25:86-91.

44. Cinque P., Cleator G.M., Weber T., et al. The role of laboratory investigation in the diagnosis and management of patients with suspected herpes simplex encephalitis: a consensus report. J Neurol Neurosurg Psychiatry 1996;61:339-45.

45. Lakeman F.D., Whitley R.J., NIAID Collaborative Antiviral Study Group. Diagnosis of Herpes simplex encephalitis: application of polymerase chain reaction to cerebrospinal fluid from brainbiopsied patients and correlation with disease. J Infec Dis 1995; $171: 857-63$

46. Monteyne P., Laterre E.C., Sindic C.J.M. Encephalitis in immunocompetent patients due to herpes simplex virus type 1 or 2: determination by polymerase chain reaction and detection of intrathecal virus-specific oligoclonal antibodies. Acta Neurol Belg 1997;97:233-9.

47. Rowley A., Lakeman F., Whitley R., Wolinsky S. Diagnosis of herpes simplex encephalitis by DNA amplification of cerebrospinal fluid cells. Lancet 1990;335:440-1.

48. Wildemann B., Ehrhart K., Storch-Hagenlocher B., et al. Quantitation of herpes simplex virus type 1 DNA in cells of cerebrospinal fluid of patients with herpes simplex virus encephalitis. Neurology 1997;48:1341-6.

49. Davies NW, Brown LJ, Gonde J, et al. Factors influencing PCR detection of viruses in cerebrospinal fluid of patients with suspected CNS infections. J Neurol Neurosurg 2005;76(1):82-7.

50. Hart G. Syphilis tests in diagnostic and therapeutic decision making. Ann Intern Med 1986;104:368-76.

51. Jaffe H.W., Larsen A.S., Peters M., et al. Tests for treponemal antibody in CSF. Arch Intern Med 1978;138:252-5.

52. McGeeney T., Yount F., Hinthorn D.R., Liu C. Utility of the FTA-Abs test of cerebrospinal fluid in the diagnosis of neurosyphilis. Sex Transm Dis 1979;6(3):195-8.

53. Walker M., Kublin J.G., Zunt J.R. Parasitic central nervous system infections in immunocompromised hosts: malaria, microsporidiosis, leishmaniasis, and African trypanosomiasis. Clin Infect Dis 2006;42:115-25.

54. Scribner C.L., Kapit R.M., Phillips E.T., Rickles N.M. Aseptic meningitis and intravenous immunoglobulin. Ann Intern Med 1994; $121: 305-6$

55. Sekul E.A., Cupler E.J., Dalakas M.C. Aseptic meningitis associated with high-dose intravenous immunoglobulin therapy: frequency and risk factors. Ann Intern Med 1994;121:259-62. 
56. Bossolasco S., Nilsson A., Milito A., et al. Soluble CD23 in cerebrospinal fluid: a marker of AIDS related non-Hodgkin's lymphoma in the brain. AIDS 2001;15:1109-13.

57. De Luca A., Antinori A., Cingolani A., et al. Evaluation of cerebrospinal fluid EBV-DNA and IL-10 as markers for in vivo diagnosis of AIDS-related primary central nervous system lymphoma. British J Haematol 1995;90:844-9.

58. Murare S., Saio M., Takenaka K., et al. Increased levels of CSF soluble CD27 in patients with primary central nervous system lymphoma. Cancer Lett 1998;132:181-6.

59. Sadler M., Brink N.S., Gazzard B.G. Management of intracerebral lesions in patients with HIV: a retrospective study with discussion of diagnostic problems. Q J Med 1998;91:205-17.

60. Glantz M.J., Cole B.F., Glantz L.K., et al. Cerebrospinal fluid cytology in patients wiyh cancer: minimizing false-negative results. Cancer 1998;82:733-9.

61. Gondos B., King E.B. Cerebrospinal fluid cytology: diagnostic accuracy and comparison of different techniques. Acta Cytol 1976;20:542-7.

62. Rogers L.R., Duchesneau P.M., Nunez C., et al. Comparison of cisternal and lumbar CSF examination in leptomingeal metastasis. Neurology 1992;42:1239-41.

63. Shah N.T. Cytology of cerebrospinal fluid. Am J Med Technol 1982;48:829-31.

64. Watson C.W., Hajdu S.I. Cytology of primary neoplasm of the central nervous system. Acta Cytol 1977;21:40-7.

65. Sá M.J., Vaz R., Cruz C. Cerebrospinal fluid cytomorphologic findings in 41 intracranial tumors. Arq Neuropsiquiatr 1995;53:218-26.

66. Kline T.S., Speigel I.J., Tinsley M. Tumor cells in the cerebrospinal fluid. Cancer 1962;15:679-84.

67. Van Oostenbrugge R.J., Twijnstra A. Presenting features and value of diagnostic procedures in leptomeningeal metastases. Neurology 1999;53:382-5.

68. Bigner S.H., Johnston W.W. The cytopathology of cerebrospinal fluid II. Metastatic cancer, meningeal carcinimatosis and primary central nervous system neoplasm. Acta Cytol 1981;25:461-79.
69. Faller D.V., Mentzer S.J., Perrine S.P. Induction of the EpsteinBarr virus tymidine kinase gene with concomitant nucleoside antivirals as a therapeutic strategy for Epstein-Barr virus associated malignancies. Current Opin Oncol 2001;13:360-7.

70. Weller M., Stevens A., Sommer N., et al. Humoral CSF parameters in the differential diagnosis of hematologic CNS neoplasia. Acta Neurol Scand 1992;86:129-33.

71. Dillmann E., López-Karpovitch X., Alvarez-Hernández X., et al. Ferritin and malignant hemopathies. I. Ferritin in cerebrospinal fluid as an indicator of central nervous system leukemic involvement. Rev Invest Clin 1982;34:95-8.

72. Edwards M.S.B., Davis R.L., Laurent J.P. Tumor markers and cytologic features of cerebrospinal fluid. Cancer 1985;56:1773-7.

73. Freilich R.J., Krol G., De Angelis L.M. Neuroimaging and cerebrospinal fluid cytology in the diagnosis of leptomeningeal metastasis. Ann Neurol 1995;38:51-7.

74. Hug A., Storch-Hagenlocher B., Haas J., et al. Single-cell PCR analysis of the immunoglobvulin heavy-chain CDR3 region for the diagnosis of leptomeningeal involvement of B-cell malignancies using standard cerebrospinal fluid cytospins. J Neurol Sc 2004;219:83-8.

75. Oschmann P., Kaps M., Völker J., et al. Meningeal carcinomatosis: CSF cytology, immunocytochemistry and biochemical tumor markers. Acta Neurol Scand 1994;89:395.

76. Kersten M.J., Evers L.M., Dellemijn P.L.I. et al. Elevation of cerebrospinal fluid soluble CD27 levels in patients with meningeal localization of lymphoid malignancies. Blood 1996;87:1985-9.

77. Li C.Y., Ziesmer S.C., Wong Y.C., et al. Diagnostic accuracy of the immunocytochemical study of body fluids. Acta Cytol 1989;33:667-73.

78. Sampath P., Weaver C.E., Sungarian A., et al. Cerebrospinal fluid (vascular endothelial growth factor) and serologic (Recoverin) tumor markers for malignant glioma. Cancer Control 2004;11:174-180.

79. Prayson R.A., Fischler D.F. Cerebrospinal fluid cytology: an 11 year experience with 5951 specimens. Arch Pathol Lab Med 1998; $122: 47-51$. 